\title{
Usage of Heat Treatment and Modified Atmosphere Packaging to Maintain Fruit Firmness of Fresh Cut Cavendish Banana (Musa cavendishii)
}

\author{
DOI: 10.18196/pt.2020.122.126-132
}

\author{
Nafi Ananda Utama \\ Department of Agrotechnology, Faculty of Agriculture, Universitas Muhammadiyah Yogyakarta. \\ Jl. Brawijaya, Kasihan, Bantul, Yogyakarta 55183. Indonesia. \\ Corresponding author, email: nafi@umy.ac.id
}

\begin{abstract}
Increasingly healthy lifestyles and advances in technology make people tend to prefer consuming fresh-cut fruits. Modified Atmosphere Packaging (MAP) contributes to extending shelf life and improving postharvest product quality. This study was aimed to determine the effects of argon-based MAP combined with heat treatment on the quality of the fresh-cut cavendish. There were four treatments examined, consisting of the combination of MAP with $73.70 \%$ argon gas and heat treatment at $40^{\circ} \mathrm{C}$ for 5 minutes (P1), heat treatment at $40^{\circ} \mathrm{C}$ for five minutes (P2), MAP with $73.70 \%$ argon gas (P3), and without treatment (P4). Each treatment consisted of three replications, and all experimental units were stored in a storage area at a temperature of $10^{\circ} \mathrm{C}$. The variables of fruit hardness, total titratable acidity, reducing sugar content, and total phenolic compounds were observed at 0, 2, 4, 6, 8, and 10 days of storage. The results of the study showed that MAP and heat treatment could maintain freshness and slow down the degradation of fresh-cut cavendish quality. The combination of MAP treatment with $73.70 \%$ argon gas and heat treatment at $40^{\circ} \mathrm{C}$ for five minutes can slow down the degradation of fresh-cut cavendish quality and suppress the total titratable acidity formation until the end of the storage period (ten days).

Keywords: Argon gas, Fresh-cut cavendish, Heat treatment, MAP
\end{abstract}

\section{ABSTRAK}

Gaya hidup sehat dan kemajuan teknologi membuat masyarakat cenderung lebih memilih mengkonsumsi buah - buahan potong. Modified Atmosphere Packaging (MAP) memberi kontribusi dalam memperpanjang umur simpan dan meningkatkan kualitas produk pascapanen. Pada penelitian ini pengaruh MAP dengan gas argon dan heat treatment untuk mendapatkan perlakuan yang paling efektif dalam mempertahankan mutu fresh-cut cavendish diteliti. Penelitian ini menggunakan 4 perlakuan yaitu MAP dengan $73,70 \%$ gas argon dan heat treatment dengan suhu $40^{\circ} \mathrm{C}$ selama 5 menit (P1), heat treatment dengan suhu $40^{\circ} \mathrm{C}$ selama 5 menit (P2), MAP dengan 73,70 \% gas argon (P3), tanpa perlakuan (P4). Semua perlakuan disimpan dalam tempat penyimpanan dengan suhu $10^{\circ} \mathrm{C}$ dan setiap perlakuan dilakukan dengan 3 ulangan percobaan. Pengujian berupa kekerasan buah, total asam tertitrasi, gula reduksi dan total senyawa fenolik yang dilakukan 0, 2, 4, 6, 8 dan 10 hari penyimpanan. Kombinasi perlakuan MAP dengan 73,70 \% gas argon dan heat treatment pada suhu $40^{\circ} \mathrm{C}$ selama 5 menit dapat mempertahankan kualitas fresh-cut cavendish dengan tingkat kekerasan buah yang baik dan signifikan, tertekannya pembentukan total asam tertitrasi dan fenol fresh cut cavendis hingga 10 hari masa penyimpanan.

Kata Kunci: Fresh-cut cavendis, MAP, Gas argon, Heat treatment

\section{INTRODUCTION}

Consumer demand for fresh, healthy, safe, comfortable, and ready to consume fruits and vegetables has made the industry of fresh-cut fruit and vegetable rapidly grow (Allende et al., 2006). Minimally processed fruit and vegetable products can be classified as fresh products whose freshness is expected to be maintained until they are ready for consumption, but the process given does not 2003). Appropriate measures to prevent browning, inhibit tissue softening and ensure microbial safety are needed to extend shelf life and maintain product freshness (Siddiqa et al., 2020).

Banana (Musa acuminata) is a most well-known tropical fruit which contains high nutritional and antioxidant content (Wang et al., 1996). According to fixed data, bananas is the largest contributor deactivate the microbes present in the product. to production, reaching 7,264,383 tons in 2018 Unlike whole fruit, fresh-cut fruit is susceptible (Badan Pusat Statistik, 2018). High nutrition and to enzymatic browning, increased respiration, antioxidants make bananas the favorite fruit of a rapid deterioration, and microbial growth (Harker, highly active modern society who desires a practical 
diet. Bananas that are minimally processed into fresh-cut fruit products attract consumers because of the uniform size of the pieces, short preparation time, and smaller storage space. The obstacles in producing fresh-cut bananas include short shelf life, the quick change in the composition of the nutritional content, its vulnerability to damage, and quality deterioration. Therefore, it is necessary to develop new methods to extend the shelf life and maintain the quality of bananas during postharvest handling to meet consumer demand for high-quality fresh-cut 'Cavendish' bananas.

The use of Modified Atmosphere Packaging (MAP) has increased over the decades. MAP is an innovative post-harvest approach that have a positive impact on fruit quality and safety, making it an important product to extend shelf life and improve the quality of various post-harvest products (Calep et al., 2013; Calep et al., 2013a; Calep et al., 2013b; Jo et al., 2014; Lyna et al., 2019; Pinto et al., 2020). MAP is a technology that manipulates the oxygen composition by lowering it and slowing down the respiration in the fruit (Kader, 1980; Mathooko, 1996), as well as reducing moisture loss (Calep et al., 2013c). Rocculi et al. (2004) reported that Argon (Ar) gas content in non-conventional MAP combinations $\left(65 \% \mathrm{~N}_{2} \mathrm{O}, 25 \% \mathrm{Ar}, 5 \% \mathrm{CO}_{2}\right.$, and $5 \% \mathrm{O} 2$ ) that used immersion treatment in a combined solution of $0.5 \%$ ascorbic acid, $0.5 \%$ citric acid, and $0.5 \%$ calcium chloride for three minutes could maintain fresh quality and secondary metabolite content in apples for 12 days.

In addition, the use of gas and heat treatment (HT) can also extend the shelf life of post-harvest products. Research by Rocculi et al. (2005) showed that MAP that consists of $90 \%$ argon gas and nitrogen dioxide produced a better result in maintaining secondary metabolites and hardness quality in fresh-cut kiwi fruit. Prasad et al. (2015) stated that immersing bananas at a temperature of $40{ }^{\circ} \mathrm{C}$ for
5 minutes was proven to inhibit microbial growth and delay ripening. This study was aimed to assess the ability of MAP and HT to maintain the quality of fresh-cut Cavendish banana fruit.

\section{MATERIALS AND METHODS}

Sorting and Preparation of Cavendish Banana

The bananas were sorted by their uniform size, freshness, and shape, according to the criteria for A-quality (3-4 bananas with yellowish color in 1 $\mathrm{kg})$. The fruits were also sorted with the same level of ripeness and good packaging. The ripeness level used was phase 2 with the ripeness index based on the color change index of 5 , in which the entire surface of the banana peel is yellow, and the tip is green. The ripeness level of bananas consists of two phases, namely phase 1 (unripe banana) and 2 (ripe banana), with a color change index of 1 to 4 and 5 to 8 , respectively (Indarto and Murinto, 2017). The bananas were then washed, cleaned, and peeled first before vertically cut into $6-8$ slices each. They were then put into a package based on the treatments and stored in a cooler at $10{ }^{\circ} \mathrm{C}$ for ten days.

\section{Experimental Set Up}

The heating treatment was carried out by preparing a water bath filled with water and heated to a temperature of $40^{\circ} \mathrm{C}$. The sliced banana was then put into the water bath for 5 minutes. A timer and thermometer were used during the heating process to maintain the temperature and time. After being heated for 5 minutes, the bananas were drained and cooled to room temperature before being put into the package.

The treatments tested were MAP with $73.70 \%$ argon gas combined with heat treatment at $40^{\circ} \mathrm{C}$ for 5 minutes, heat treatment at $40^{\circ} \mathrm{C}$ for 5 minutes, MAP with $73.70 \%$ argon gas, and without MAP nor heat treatment (control). Argon (Ar) 
was applied after the heating treatment. After they were cooled, the bananas were put into zip-locked plastic that had been vacuumed to remove their gas composition. After that, argon gas was inserted into the plastic and the plastic was closed. The packaged bananas were then stored in a cooler with a temperature of $10^{\circ} \mathrm{C}$ for ten days. The variables examined in this research included fruit hardness, total titratable acidity, total phenolic compound, and reducing sugar content, observed on $0,2,4$, 6,8 , and 10 days of storage.

\section{Fruit Hardness ( $\left.\mathrm{N} / \mathrm{mm}^{2}\right)$}

The fruit hardness test was conducted to determine the change in the level of hardness of the fruit samples under observation. The texture or hardness of the fruit was measured using a penetrometer (Lutron, FR-520, USA). In the tested fruit, the tip of the penetrometer was inserted into the fruit at three different parts. The value obtained shown by the penetrometer is the force value acquired in the calculation.

\section{Titratable Acidity}

The total titratable acidity test was carried out to determine the total organic acid in the sample solution using the titration method. This test was carried out by mixing 5 grams of the pureed sample with $70 \mathrm{ml}$ of distilled water in a $100 \mathrm{ml}$ volumetric flask. The sample solution was shaken until homogeneous and $20 \mathrm{ml}$ of it was filtered into Erlenmeyer flasks. After that, 2-3 drops of 1\% PP indicator were added to the sample solution and titrated with $0.1 \mathrm{~N} \mathrm{NaOH}$ until the color of the solution turned pink, and the color did not fade after 30 seconds.

\section{Reducing Sugar Content}

The reducing sugar content was tested using the Nelson-Smogiy (NS) method. The NS method uses nelson $\mathrm{C}$ and standard sugar solutions to determine the equation for reducing sugar content. The test was carried out by mixing 1 gram of the sample with $100 \mathrm{ml}$ of distilled water and shaking it until it was homogeneous. After that, the sample solution was filtered using filter paper, then $0.1 \mathrm{ml}$ of the filtrate was taken and mixed with $0.9 \mathrm{ml}$ of distilled water and $1 \mathrm{ml}$ of nelson $\mathrm{C}$ in a test tube. The mixed filtrate was then put into a water bath with a temperature of $70^{\circ} \mathrm{C}$ for 20 minutes and let still for 30 minutes, before added with $1 \mathrm{ml}$ arsenic and $7 \mathrm{ml}$ distilled water and shaken until homogeneous. Next, the absorbance was measured with a spectrophotometer (Thermo, Genesis 30, USA) at a wavelength of $540 \mathrm{~nm}$.

\section{Total Phenolic Compound}

According to Singleton and Rossi (1965), total phenolic compounds can be tested using the FolinCiocalteu method. In this method, the absorbance measurement is at a wavelength of $750 \mathrm{~nm}$. The extract was made by dissolving $1 \mathrm{~g}$ of mashed banana flesh in $10 \mathrm{ml}$ of distilled water. A total of $0.5 \mathrm{ml}$ of the solution was taken and mixed with $5 \mathrm{ml}$ of distilled water, then shaken and let still for 5 minutes. After that, $1.5 \mathrm{ml}$ of $5 \% \mathrm{Na} 2 \mathrm{CO} 3$ and 1.5 folin was added to the mixture, which was then shaken. Then measurements were made using a spectrophotometer (Thermo, Genesis 30, USA) at a wavelength of $750 \mathrm{~nm}$ (Khadambi, 2007).

\section{Data Analysis}

The experiment in this study was arranged in a completely randomized design (CRD) with a single factor. The observation data were analyzed using analysis of variance (ANOVA) with a level of 5\%. The data showing significant differences between treatments were then tested with the Duncan multiple range test using SPSS XII software. 


\section{RESULTS AND DISCUSSION}

\section{Fruit hardness}

Fruit hardness is a parameter that is considered the most objective in determining the freshness of a product. the fruit hardness of the bananas decreased in all treatments. The treatments given to the fresh-cut banana fruit resulted in better fruit hardness than the control. Changes in fruit texture are influenced by cellulose and pectin compounds. When it ripens, the fruit will become soft due to a decrease in these compounds (Chauhan et al., 2006; Prasad et al., 2015). MAP treatment with argon gas and heat treatment was thought to be able to maintain cellulose and pectin compounds content during storage. This is because the treatments can suppress uncontrolled cell adhesion in the middle lamellae in the fruit cell walls, as well as inhibiting the breakdown of the pectin compounds.

Argon gas can maintain fruit hardness (Shen et al., 2019). Based on the analysis of variance (Table 1), MAP with argon gas combined with heat treatment showed a significantly better fruit hardness compared to either heat treatment or MAP treatment only. These results indicate that pectin breakdown can be suppressed well with the usage of argon gas and heat treatment. Heat treatment can inhibit fruit softening, lose total titrated acid, increase the antioxidant potential, and maintain the quality of peaches (Huan et al., 2018).

Table 1. Fruit Hardness of Banana as Affected by MAP and Heat Treatment $\left(\mathrm{N} / \mathrm{mm}^{2}\right)$

\begin{tabular}{lcccccc}
\hline \multirow{2}{*}{ Treatment } & \multicolumn{6}{c}{ The average fruit hardness on n-days } \\
\cline { 2 - 7 } & 0 & 2 & 4 & 6 & 8 & 10 \\
\hline P1 & $0.227 a$ & $0.217 a$ & $0.200 a$ & $0.170 a$ & $0.150 a$ & $0.147 a$ \\
P2 & $0.223 a$ & $0.203 b$ & $0.200 a$ & $0.137 c$ & $0.123 b c$ & $0.130 b$ \\
P3 & $0.233 a$ & $0.213 a b$ & $0.203 a$ & $0.170 a$ & $0.137 a b$ & $0.123 b$ \\
P4 & $0.230 a$ & $0.203 b$ & $0.183 b$ & $0.150 b$ & $0.107 c$ & $0.090 c$ \\
\hline
\end{tabular}

Note: values followed by the same letters within the same column are not significantly different according to DMRT at $5 \%$. Remarks: P1: heat treatment at $40{ }^{\circ} \mathrm{C}$ for 5 minutes combined with Argon (Ar) gas of $73.70 \%$, P2: heat treatment at $40^{\circ} \mathrm{C}$ for 5 minutes, P3: Argon (Ar) gas of $73.70 \%$, P4: without treatment.

\section{Total Titratable Acidity}

The total acid content in the sample fluctuated from the beginning to the end of the experiment. During the first eight days of observation, all treatments showed an increase in total acid content (Figure 1). The acid content in the control treatment decreased on day 8 , and it increased on day 10 when acid content in other treatments began to decrease. MAP treatment and heat treatment showed no significant difference in the total acid content of the fresh-cut cavendish bananas. However, the treatment showed a stable increase in acid meaning that the condition of the packaging with controlled air suppressed the breakdown of complex materials caused by cellular respiration in the fruit. The acidity of the fresh-cut cavendish bananas was inversely related to the fruit hardness. If the fruit hardness can be suppressed, its acidity will increase (Ghasemnezhad, 2011).

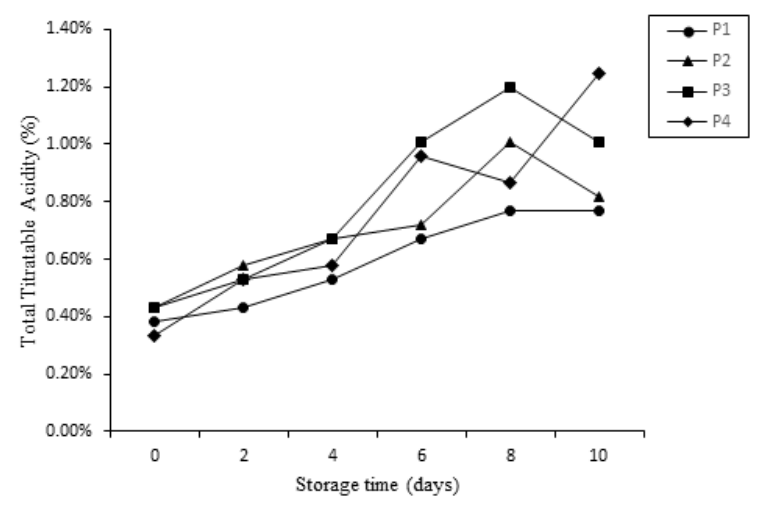

Figure 1. Change of Total Titratable Acidity During Storage of Heat Treatment and MAP. P1: heat treatment at $40^{\circ} \mathrm{C}$ for 5 minutes combined with Argon (Ar) gas of 73.70 $\%$, P2: heat treatment at $40{ }^{\circ} \mathrm{C}$ for 5 minutes, P3: Argon (Ar) gas of $73.70 \%$, P4: without treatment.

MAP suppresses fruit respiration, making the resulting organic acids unusable in the respiration process, thereby increasing total acid content. However, cutting the fruit causes the fruit to become damaged and increases the respiration rate. In packaging with the MAP and HT, the respiration rate was suppressed. This result is supported by Shen et al. (2019), who reported that the use of 
the MAP method in storing figs could suppress respiration during the storage period.

\section{Reducing sugar content}

Sugar in fruit generally increases at the beginning of the storage and then decreases at the end of the storage period. The MAP with the addition of argon gas combined with HT showed an increase in reducing sugar on the $6^{\text {th }}$ day (Figure 2 ). The addition of argon gas can suppress respiration that occurs in fruit (Calep et al., 2013b). The respiration rate suppressed by the argon gas treatment inhibited the degradation of starch into sugar. The use of controlled air packs is better at suppressing the reduction of banana fruit sugar on the 12th day of storage (Zewter, 2012). Pinto et al. (2020) stated that climacteric fruit such as bananas show decreased starch content and increased total sugar during the peak ripening process under normal conditions.

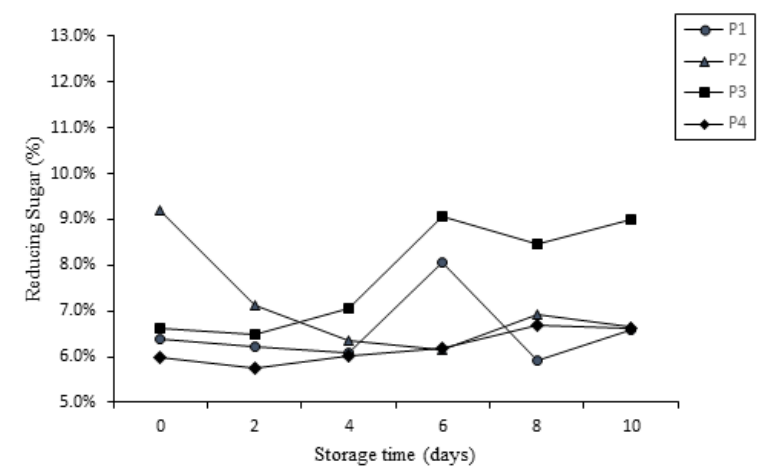

Figure 2. Change of Reducing Sugar During Storage of Heat Treatment and MAP. P1: heat treatment at $40{ }^{\circ} \mathrm{C}$ for 5 minutes combined with Argon (Ar) gas of $73.70 \%$, P2: heat treatment at $40{ }^{\circ} \mathrm{C}$ for 5 minutes, P3: Argon (Ar) gas of $73.70 \%$, P4: without treatment.

The addition of argon gas also showed a positive effect on the fruit hardness. These results show that the respiration rate can be suppressed properly by the MAP method. This rate of respiration increases the amount of reducing sugar in the MAP method, supported by low-temperature storage that affects the increase in reducing sugar in bananas. This re- sult is in accordance with the results of Vilas-Boas et al. (2006), which stated that storing bananas in cold or low temperatures increases the reducing sugar content on the 3 rd day of storage when compared to the room temperature.

MAP with argon combined with HT was able to increase the reducing sugar content. The sugar decomposition can be caused by the respiration that takes place in the fruit. In climacteric fruit, changes in sugar content is related to the total acid in the fruit. The total sugar content in climacteric fruit decreases further during the ripening process in the open space. The decrease occurs because the respiration process of the fruit is not suppressed, making starch degrade faster.

\section{Total phenolic compounds}

The total phenolic compounds in all treatments fluctuated in each storage day. The cutting caused an increase in the phenolic content in the banana pulp tissue on the 2 nd to 4 th day of observation (Figure 3). The phenolic content of the fresh-cut banana pulp increased after 6 hours and continued to increase to 3.7 and 4.5 times higher than that of the uncut pulp at 24 and 36 hours, respectively (Chena et al., 2008). Phenolic compounds oxidized by the polyphenol oxidase (PPO) enzyme are the cause of browning in fruits and vegetables, including bananas (Nguyen et al., 2003). The phenolic compounds in MAP with argon gas without HT decreased to its lowest on day 6. Bananas with MAP combined with chemical immersion produced the lowest PPO activity and phenolic compounds in 5 days of storage (Siddiqa et al., 2020). The cutting led to a significant increase in PAL activity. PAL activity in fresh-cut pulp tissue markedly increased from about 1.6 moles of cinnamic acid mg protein- 1 hour- 1 at 0 hours after cutting to a peak of about 5.6 moles cinnamic acid mg protein-1 hour-1 at 18 hours after cutting (Belay et al., 2019). 


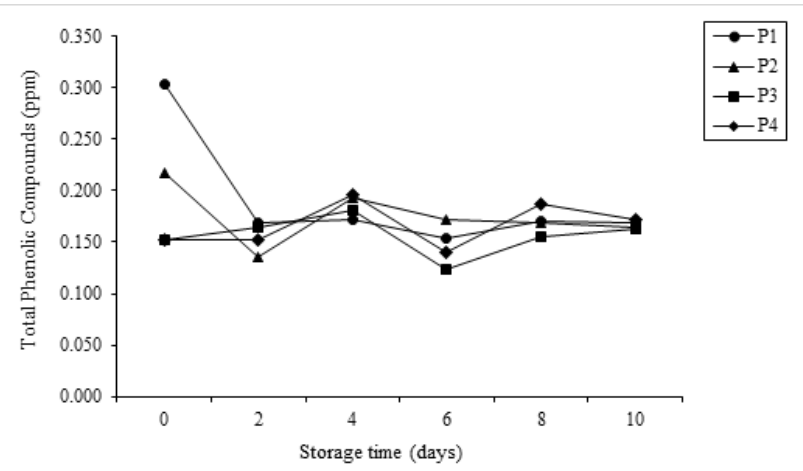

Figure 3. Change of Total Phenolic Compounds During Storage of Heat Treatment and MAP. P1: heat treatment at 40 ${ }^{\circ} \mathrm{C}$ for 5 minutes combined with Argon (Ar) gas of 73.70 $\%$, P2: heat treatment at $40^{\circ} \mathrm{C}$ for 5 minutes, P3: Argon (Ar) gas of $73.70 \%$, P4: without treatment.

The accumulation of phenolic compounds varies depending on the commodity, genotype, oxygen concentration, storage time, and temperature (Ghasemnezhad et al., 2011; Hidayati, 2012). MAP and HT were unable to significantly keep total phenol stable. MAP on fresh-cut fruits under certain conditions causes various effects and responses to the reduced respiration, as well as to the changes in color, texture, and concentration of bioactive compounds as effects of fermentative metabolites (Kudachikar et al., 2011; Belay et al., 2019)

\section{CONCLUSION}

Modified atmosphere packaging (MAP) and heat treatment (HT) as an inhibitor to the ripening process could maintain the quality of the fresh-cut cavendish bananas. The treatment of MAP with $73.70 \%$ argon gas combined with heat treatment at $40{ }^{\circ} \mathrm{C}$ for five minutes could maintain the fruit hardness level and suppress the total titratable acidity for ten days of storage. These results can be used as the basis for further research regarding the concentration of argon gas as control of gas composition in packaging to maintain the quality of fresh-cut cavendish bananas before the peak maturity period (ripening index of 1-4).

\section{ACKNOWLEDGMENT}

The author would like to thank Universitas Muhammadiyah Yogyakarta for the funding of International Research Collaboration scheme.

\section{REFERENCES}

Allende, F.A. Tomas-Barberan, MI.Gil. (2006). Minimal processing for healthy traditional foods. Trends Food Sci. Technol. 16, 513519. https://doi.org/10.1016/j.tifs.2006.04.005

Badan Pusat Satistik. (2018). Statistik Indonesia. Direktorat Jendral hortikultura.

Belay, ZA, Caleb, OJ, Opara, UL. (2019). Influence of initial gas modification on physicochemical quality attributes and molecular changes in fresh and fresh-cut fruit during modified atmosphere packaging. Food Packaging and Shelf life. Vol. 21. Doi://doi.org/10.1016/j.fpsl.2019.100359

Calep, 0.J, Mahajan, PV, Manley, M., Opara, UL. (2013). Evaluation of parameters affecting modified atmosphere packaging engineering design for pomegranate arils. International Journal of Food Science and Technology, 48(11), 2315-2323. https:// doi.org/10.1111/ijfs.12220

Calep, OJ., Mahajan, PV., AL-Said, FAJ., Opara, UL. (2013a). Modified atmosphere packaging technology of fresh and fresh-cut produce and the microbial consequences- $A$ review. Food and Bioprocess Technology, 6(2), 303-329. doi: 10.1007/s11947012-0932-4

Calep, OJ., Mahajan, PV., AL-Said, FAJ., Opara, UL. (2013b). Transpiration rate and quality of pomegranate arils as affected by storage conditions. Food and Bioprocess Technology, 11(3), 199-207. https://doi.org/10.1080/19476337.2012.721807

Calep, OJ., Opara, UL., Mahajan, P.V., Manley, M., Mokwena, L., Tredoux, A.G. (2013c). Effect of modified atmosphere packaging and storage temperature on volatile composition and postharvest life of minimally-processed pomegranate arils (cvs.'Acco'and 'Herskawitz'). Postharvest abiology and Technology, 79, 54-61. https://doi.org/10.1111/j.1750-3841.2012.02623.x

Chauhan, OP., Raju, PS., Dasgupta, DK., Bawa, AS. (2006). Modified atmosphere packaging of banana (cv. Pachbale)with Ethylene, Carbon di-oxide and Moisture scrubbers and effect on its ripening behaviour. American Journal of Food Technology 1 (2), 179-189, 2006. ISSN 1557-4571. http://doi.org/10.3923/ ajft.2006.179.189

Chena, J., Hea, L., Jiang, Y, Kuanga, J., Lud, C., Joycee, DC., Macnishf, A., He, YX., Lua, W. (2008). Expression of PAL and HSPs in fresh-cut banana fruit. Environmental and experimental botany 66, 31-37 http://doi.org/10.1016/j.envexpbot.2008.12.019

Ghasemnezhad, M., Sherafati, M., Payvast, G.A. (2011). Variation in phenolic compounds, ascorbatic acid and antioxidant activity of five coloured bell pepper (Capsicum annum) fruits at two different harvest times. Journal of Functional Foods, 3(1), 4449. https://doi.org/10.1016/j.jff.2011.02.002

Harker, FR., Gunson, FA., Jaeger, SR. (2003). The case for fruit quality: an interpretive review of consumer attitudes, and prefer- 
ences for apples . Postharvest Biology and Technology, 28, 333-347. https://doi.org/10.1016/S0925-5214(02)00215-6

Hidayati, B.A. (2012). Kajian Kombinasi Hot Water Treatment (HWT) dan CaCl2 Terhadap Mutu dan Umur Simpan Mangga Varietas Gedong Gincu (Magnifera indica, L.) (Skripsi). Institut Pertanian Bogor. Indonesia.

Huan, C., An, X., Yu, M., Jiang, L., Ma, R., Tu, M., Yu, Z. (2018). Effect of combinaed heat and 1-MCP treatment on the quality and antioxsidant level of peach fruit during storage. Postharvest Biology and Technology, 145, 193-202. https://doi.org/10.1016/j. postharvbio.2018.07.013

Indarto, I., \& Murinto, M. (2017). Deteksi Kematangan Buah Pisang Berdasarkan Fitur Warna Citra Kulit Pisang Menggunakan Metode Transformasi Ruang Warna HIS. JUITA: Jurnal Informatika, 5(1), 15-21.

Jo, YH., AN, DS., Lee, DS.2014. Active air flushing in a sensorcontrolled fresh produce container system to maintain the desired modified atmosphere. Biosystems Engineering 125, 122-127. https://doi.org/10.1111/jfpp.14757

Kader, A. A. (1980). Prevention of ripening in fruits by use of controlled atmospheres. Food Technol, 34(3), 51-54.

Khadambi, T. N. (2007). Extraction of phenolic compounds and quantification of the total phenol and condensed tannin content of bran fraction of condensed tannin and condensed tannin free sorghum varieties. University of Pretoria etd, Pretoria, 1(0), 1.

Kudachikar, V.B., Kulkarni, S.G., and Prakash, M.N. (2011). Effect of modified atmosphere packaging on quality and shelf life of 'Robusta' banana (Musa sp.) stored at low temperature. Journal of Food Science and Technology 48: 319-324. https://doi. org/10.1007/s13197-011-0238-y

Lyna, FH., Adilaha Z.A.M., Nor-Khaizurab, M.A.R., Jamilaha, B., Hanani, Z.A.N. 2020. Application of modified atmosphere and active packaging for oyster mushroom (Pleurotus ostreatus). Food Packaging and Shelf Life 23, https://doi.org/10.1016/j. fpsl.2019.100451

Mathooko, F.M (1996). Regulation of respiratory metabolism in fruits and vegetables by carbon dioxide. Postharvest Biology and Technology, 9(3), 247-264. https://doi.org/10.1016/ S0925-5214(96)00019-1

Nguyen, T.B.T., Ketsa, S., Van Doorn, W.G. (2003). Relationship Between Browning and The Activities of Polyphenol Oxidase and Phenylalanine Ammonia Lyase in Banana Peel during Low Temperature Storage. Postharvest Biology and Technology, 30, 187-193. https://doi.org/10.1016/S0925-5214(03)00103-0
Pinto, L, Palma, A, Cefola, M, Pace, B, D'Aquino, S, Carboni, C, Baruzzi, F. (2020). Effect of modified atmosphere packaging (MAP) and gaseous ozone pre-packing treatment on the physico-chemical, microbiological and sensor quality of small berry fruit. Food Packagung and Shelf Life 26, https://doi.org/10.1016/j. fpsl.2020.100573

Prasad, R., R.B. Ram, Vikas, K., Sandeep, K.R. (2015). Study on Effect of Different Packaging Materials on Shelf Life of Banana (Musa Paradisiaca L.) cv. Harichal Under Different Conditions. International Journal of Pure and Applied Bioscience, 3(4), 132-141.

Rocculi, P., Romani, S., Dalla Rosa, M., 2004. Evaluation of physicochemical parameters of minimally processed apples packed in non-conventional modified atmosphere. Food Res. Int. 37, 329-335. https://doi.org/10.1016/j.postharvbio.2004.09.003 Rocculi, P., Romani, S., Rosa, M.D (2005). Effect of MAP with argon and nitrous oxide on quality maintenance of minimally processed kiwifruit. Postharvest Biology and Technology 35, 319-328. https://doi.org/10.1016/j.postharvbio.2004.09.003

Siddiqa, R., Aurasa, R., Siddiq, M., Dolan, K.D., Hartea, B. (2020). Effect of modified atmosphere packaging (MAP) and Nature Seal treatment on the physico-chemical, microbiological, and sensory quality of fresh-cut d'Anjou pears. Jurnal Food Packaging and shelf life, 23. https://doi.org/10.1016/j.fpsl.2019.100454.

Singleton, V.L., and J.A., Rossi. (1965). Colorimetry of Total Phenolic with Phosphomolybdic-Phosphotungstic Acid Reagent. American Journal Enologi and Viticulture, 16, 147.

Shen, Xu., Zhang, M., Devahastin, S., Guo, Z. (2019). Effects of pressurized argon and nitrogen treatments in combination with modified atmosphere on quality characteristics of fresh-cut potatoes. Postharvest Biology and Technology, 149, 159-165. https://doi.org/10.1016/j.postharvbio.2018.11.023

Vilas-Boas, E.de.B., Adel, A.K. (2006). Effect of Atmospheric Modification, 1-MCP and Chemicals on Quality of Fresh-cut Banana. Postharvest Biologi and Technology, 39, 155-162. https://doi. org/10.1016/j.postharvbio.2005.09.010

Wang, H., Cao ,G., Prior, R.L. (1996). Total Antioxidant Capacity of Fruit. J. Agric. Food Chem, 44, 701-7. https://doi.org/10.1080 /10942912.2010.499039

Zewter, A., K. Woldetsadik, T.S. Workneh. (2012). Effect of 1-methylcyclopropene, potassium permanganate and Packaging on Quality of Banana. African Journal of Agricultural Research, 7(16), 2425-2437. https://doi.org/10.5897/AJAR11.1203 